\title{
THE EFFECT OF ACTH AND CORTISONE ON CEREBRAL BLOOD FLOW AND METABOLISM ${ }^{1}$
}

\author{
BY WILLIS SENSENBACH, LEONARD MADISON, AND LAMAR OCHS
}

(From the Department of Internal Medicine of the Southwestern Medical School of the University of Texas, Dallas, and the Medical Service of the Veterans Administration

Hospital, Dallas, Texas)

(Submitted for publication October 24, 1952; accepted December 31, 1952)

Mental aberrations of various types and in varying degree are observed in many patients during the administration of ACTH or cortisone. Most often the changes are those of personality or mood; restlessness, irritability, insomnia, elation, depression, euphoria are among the more common manifestations. Less commonly, but nonetheless, not rarely, frankly psychotic episodes occur. In Cushing's syndrome, where there is an abundance of endogenous adrenal cortical hormones, there is a high incidence of abnormal mentation including hysteria, suicidal depressive states, simple schizophrenia and paranoia (1). The production of mental symptoms and psychoses consequent to the administration of ACTH or cortisone and their frequency in Cushing's syndrome suggest the possibility that there is a biochemical basis for certain of the psychoses and personality disorders.

This report deals with the study of the cerebral circulation and metabolism before, during, and after the administration of ACTH and cortisone for the purpose of determining the cerebral hemodynamic and metabolic effects of these hormones and possibly of elucidating the relationship of the physiological derangements to the induced mental aberrations.

\section{METHOD}

The cerebral blood flow (CBF) was determined by the nitrous oxide method of Kety and Schmidt (2) as modified by Scheinberg and Stead (3) except in the case of T.B.C. where the original method (2) was employed. The cerebral oxygen consumption $\left(\mathrm{CMR}_{\mathrm{O}_{2}}\right)$ and cerebral glucose consumption (CMRglu) were calculated from the $\mathrm{CBF}$ and the arterio-cerebral venous oxygen and glucose differences. The cerebral vascular resistance (CVR) was calculated from the CBF and the mean arterial blood

${ }^{1}$ Reviewed in the Veterans Administration and published with the approval of the Chief Medical Director. The statements and conclusions published by the authors are the result of their own study and do not necessarily reflect the opinion or policy of the Veterans Administration. pressure which was measured directly from a peripheral artery, usually the femoral, with a damped mercury manometer. Arterial and cerebral venous blood samples were drawn simultaneously just before each blood flow procedure. Blood oxygen and carbon dioxide content were determined manometrically (2). Blood sugar was determined by Nelson's modification of the Somogyi method (4).

Complete studies of cerebral hemodynamics and metabolism were undertaken on 45 occasions in 12 patients in the ACTH 2 group. These comprised pretreatment determinations in 11 of the 12 patients; from one to six determinations on each patient during the time they were receiving $10 \mathrm{mgms}$. to $200 \mathrm{mgms}$. of ACTH daily; and in many instances, as a further control, studies were repeated 10 to 20 days after cessation of hormone therapy.

The observations during the treatment period in 9 of the 12 patients in the ACTH group were performed after the patients had received the drug for two to three weeks. In three instances (E.R.S., L.R.C., and J.R.B.), longterm studies extending from three to eight months were performed, during which time repeated observations were made. The data obtained from 2 patients with Cushing's syndrome are also included.

Thirty-two studies were performed on a second group of 9 patients who received cortisone in doses ranging from 100 to $200 \mathrm{mgms}$. daily. Pretreatment, treatment, and post-treatment studies were performed on at least one occasion in each patient at about the same time intervals as those in the ACTH group.

The data were analyzed statistically by the method of paired observations; the pertinent difference between values obtained before and during administration of the hormone were calculated for each subject. The mean of those differences together with its standard error was then calculated from the individual differences. $P$ values so determined are recorded in Tables I to IV. Where multiple studies on one patient were done, the values were averaged and this average was used in the calculation of individual differences, standard deviation and standard error.

\section{RESULTS}

Cortisone. The results of studies made before, during and after the administration of cortisone

${ }^{2}$ We are indebted to Dr. John R. Mote of the Armour Laboratories, Chicago, Illinois, for making available the ACTH used in these studies. 
TABLE I

The effect of cortisone on cerebral hemodymamic and metabolic functions

\begin{tabular}{|c|c|c|c|c|c|c|c|c|c|c|c|c|c|c|c|c|c|c|}
\hline \multirow{2}{*}{ Subject } & \multirow{2}{*}{ Diagnosis } & \multirow{2}{*}{ Age } & \multirow{2}{*}{$\begin{array}{l}\text { Daily } \\
\text { dose } \\
\text { Corti- } \\
\text { sone } \\
\text { mgms./ } \\
\text { day }\end{array}$} & \multicolumn{3}{|c|}{$\begin{array}{c}\text { Cerebral blood } \\
\text { flow (CBF) } \\
c c . / m i x . / 100 \mathrm{sms} .\end{array}$} & \multicolumn{3}{|c|}{$\begin{array}{c}\text { Cerebral vascular } \\
\text { resistance (CVR) } \\
\mathrm{mm} . \mathrm{Hg}_{\mathrm{g}} / \mathrm{cc} . / \mathrm{min} . / \\
100 \mathrm{sms} .\end{array}$} & \multicolumn{3}{|c|}{$\begin{array}{l}\text { Mean arterial } \\
\text { blood pressure } \\
\text { (MABP) } \\
\text { mm. Hg }\end{array}$} & \multicolumn{3}{|c|}{$\begin{array}{l}\text { Cerebral metabolic } \\
\text { rate oxygen } \\
\text { (CMRO2) } \\
\text { c../min./100 gms. }\end{array}$} & \multicolumn{3}{|c|}{$\begin{array}{l}\text { Cerebral metabolic } \\
\text { rate glucose } \\
\text { (CMRglu) } \\
\text { mgms./min./100 gms. }\end{array}$} \\
\hline & & & & $\begin{array}{l}\text { Pre- } \\
\text { treat- } \\
\text { ment }\end{array}$ & $\begin{array}{c}\text { Treat- } \\
\text { ment }\end{array}$ & $\begin{array}{l}\text { Post- } \\
\text { treat- } \\
\text { ment }\end{array}$ & $\begin{array}{l}\text { Pre- } \\
\text { treat- } \\
\text { ment }\end{array}$ & $\begin{array}{c}\text { Treat- } \\
\text { ment }\end{array}$ & $\begin{array}{l}\text { Post- } \\
\text { treat- } \\
\text { ment }\end{array}$ & $\begin{array}{l}\text { Pre- } \\
\text { treat- } \\
\text { ment }\end{array}$ & $\begin{array}{c}\text { Treat- } \\
\text { ment }\end{array}$ & $\begin{array}{l}\text { Post- } \\
\text { treat- } \\
\text { ment }\end{array}$ & $\begin{array}{l}\text { Pre- } \\
\text { treat- } \\
\text { ment }\end{array}$ & $\begin{array}{c}\text { Treat- } \\
\text { ment }\end{array}$ & $\begin{array}{l}\text { Post- } \\
\text { treat- } \\
\text { ment }\end{array}$ & $\begin{array}{c}\text { Pre- } \\
\text { treat- } \\
\text { ment }\end{array}$ & $\begin{array}{l}\text { Treat- } \\
\text { ment }\end{array}$ & $\begin{array}{l}\text { Post- } \\
\text { treat- } \\
\text { ment }\end{array}$ \\
\hline T. B. C. & $\begin{array}{l}\text { Rheumatoid } \\
\text { arthritis }\end{array}$ & 38 & 100 & 51 & 44 & 54 & 1.35 & 1.79 & 1.27 & 68 & 79 & 69 & 2.91 & 2.68 & 3.38 & & & \\
\hline L. N. W. & $\begin{array}{l}\text { Rheumatoid } \\
\text { arthritis }\end{array}$ & 26 & 100 & 76 & 67 & 78 & 1.00 & 1.08 & 0.98 & 76 & 73 & 77 & 4.13 & 4.14 & 4.36 & 3.80 & 7.37 & 8.58 \\
\hline R. H. H. & $\begin{array}{l}\text { Periarteritis } \\
\text { nodosa }\end{array}$ & 33 & $\begin{array}{l}100 \\
200\end{array}$ & 59 & $\begin{array}{l}66 \\
74 \\
(70) *\end{array}$ & 43 & 1.23 & $\begin{array}{l}1.22 \\
1.21 \\
(1.22)\end{array}$ & 1.60 & 73 & $\begin{array}{c}81 \\
90 \\
(86)\end{array}$ & 69 & 3.75 & $\begin{array}{r}4.74 \\
4.82 \\
(4.78)\end{array}$ & 2.73 & 5.31 & \begin{tabular}{c|}
8.58 \\
5.92 \\
$(7.25)$ \\
\end{tabular} & 3.87 \\
\hline H. G. & $\begin{array}{l}\text { Ulcerative } \\
\text { colitis }\end{array}$ & $\overline{26}$ & 100 & 58 & 46 & 55 & 1.27 & 1.39 & 1.05 & 74 & 64 & 58 & 2.61 & 2.61 & 3.12 & 5.22 & 3.22 & 5.50 \\
\hline D. L. G. & Dermatitis & 32 & 200 & 53 & 53 & 52 & 1.35 & 1.39 & 1.36 & 72 & 74 & 71 & 4.12 & 4.00 & 4.10 & 5.83 & 4.77 & 3.64 \\
\hline D. S. & $\begin{array}{l}\text { Rheumatoid } \\
\text { arthritis }\end{array}$ & 28 & 200 & 57 & 54 & 53 & 1.26 & 1.35 & 1.32 & 72 & 73 & 70 & 3.32 & 3.27 & 3.20 & 3.99 & 4.86 & 4.24 \\
\hline C. A. & Silicosis & 53 & 100 & 49 & $\begin{array}{c}54 \\
43 \\
(49) \\
\end{array}$ & 45 & 1.85 & $\begin{array}{c}2.00 \\
2.58 \\
(2.29) \\
\end{array}$ & 2.11 & 91 & $\begin{array}{l}108 \\
111 \\
(110)\end{array}$ & 95 & 3.18 & $\begin{array}{r}3.56 \\
3.14 \\
(3.35)\end{array}$ & 3.55 & & 5.16 & 3.60 \\
\hline R. G. & Scleroderma & 57 & 100 & 70 & 73 & $\begin{array}{l}45 \\
51 \\
(48)\end{array}$ & 1.21 & 1.59 & $\begin{array}{l}2.07 \\
1.53 \\
(1.80)\end{array}$ & 85 & 116 & $\begin{array}{c}93 \\
78 \\
(86) \\
\end{array}$ & 3.77 & 4.54 & $\begin{array}{c}3.04 \\
3.73 \\
(3.39)\end{array}$ & 4.20 & 2.92 & $\begin{array}{l}5.85 \\
1.53 \\
(3.64)\end{array}$ \\
\hline T. J. L. & $\begin{array}{l}\text { Eczematoid } \\
\text { dermatitis }\end{array}$ & 58 & $\begin{array}{l}100 \\
200\end{array}$ & 110 & $\begin{array}{c}114 \\
58 \\
(86)\end{array}$ & $\begin{array}{c}68 \\
88 \\
(78)\end{array}$ & 0.66 & $\begin{array}{l}0.78 \\
1.48 \\
(1.13)\end{array}$ & \begin{tabular}{c|}
1.13 \\
0.75 \\
$(0.94)$ \\
\end{tabular} & 73 & $\begin{array}{c}90 \\
86 \\
(88)\end{array}$ & $\begin{array}{l}77 \\
66 \\
(72)\end{array}$ & 4.35 & $\begin{array}{c}4.45 \\
2.92 \\
(3.69)\end{array}$ & $\begin{array}{r}2.60 \\
3.56 \\
(3.03) \\
\end{array}$ & 11.0 & $\begin{array}{c}5.70 \\
4.64 \\
(5.17)\end{array}$ & $\begin{array}{c}3.40 \\
5.28 \\
(4.34)\end{array}$ \\
\hline Mean & & & & 64.7 & 60.2 & 56.2 & 1.24 & 1.47 & 1.38 & 76 & 84.8 & 74.1 & 3.57 & 3.67 & 3.43 & 5.62 & 5.09 & 4.68 \\
\hline S.D. & & & & 18.0 & 13.6 & 12.3 & .30 & .11 & .37 & 6.9 & 16.6 & 10.5 & .56 & .76 & .51 & 2.31 & 1.50 & 1.58 \\
\hline S.E. & & & & 6.4 & 4.8 & 4.3 & .10 & .04 & .13 & 2.4 & 2.8 & 3.3 & .20 & .27 & .16 & .94 & .57 & .60 \\
\hline P Value & & & & & $>0.2$ & & & $<.01$ & & & $<.05$ & & & $>0.5$ & & & $>0.5$ & \\
\hline
\end{tabular}

* Values in parentheses are averages for the multiple determination listed.

to nine subjects are presented in Table I and Table II. There were significant increases in the mean CVR from 1.24 to $1.47 \mathrm{~mm}$. $\mathrm{Hg}$ per cc. per min. per 100 gms. ( $P=<.01)$, and MABP from 76 to $84.8 \mathrm{~mm}$. $\mathrm{Hg}(\mathrm{P}=<.05)$ during cortisone therapy. However, consequent to a parallel increase in both these values, no change in CBF occurred $(P=>.2)$. Neither the increase in $\mathrm{CMR}_{\mathrm{O}_{2}}$ from 3.57 to $3.67 \mathrm{cc}$. per min. per 100 gms. ( $\mathrm{P}=>.5)$, nor the changes observed in the CMRglu $(\mathrm{P}=>.5)$ were significant.

$A C T H$. The data obtained from studies made before, during, and after the administration of ACTH to 12 subjects are presented in Tables III and IV. The mean CBF was unaltered during ACTH therapy $(P=>.5)$. The increase in MABP (77.2 to $85.3 \mathrm{~mm}$. $\mathrm{Hg}$ ) is highly significant $(\mathrm{P}=<.001)$; the changes in mean CVR $(1.29 \mathrm{~mm}$. $\mathrm{Hg}$ per cc. per min. per $100 \mathrm{gms}$. to $1.59 \mathrm{~mm}$. $\mathrm{Hg}$ per cc. per min. per 100 gms.) $(\mathrm{P}=>.05)$, mean $\mathrm{CMR}_{\mathrm{O}_{2}}$ (3.69 cc. per min. per 100 gms. to $3.96 \mathrm{cc}$. per min. per 100 gms.) $(\mathrm{P}=>.3$ ), and mean CMRglu (5.48 mgms. per min. per 100 gms. to 5.25 mgms. per min. per 100 gms.) $(\mathrm{P}=>.7)$ are not. Although the 23 per cent increase in mean CVR is not statistically significant, it is to be noted that it returned to its pretreatment control value after ACTH was discontinued.

Mean cerebral venous $\mathrm{O}_{2}$ content decreased significantly from 10.39 vol. per cent to 9.12 vol. per cent $(\mathrm{P}=<.01)$ and cerebral venous $\mathrm{CO}_{2}$ content increased from 53.44 vol. per cent to 56.81 vol. per cent $(P=<.05)$. No other significant changes in arterial or cerebral venous blood constituents occurred.

The effect of prolonged administration of $A C T H$. In the cortisone series and in most of the subjects in the ACTH series the drugs were administered as a constant dose for relatively short periods, usually two to three weeks. In the three subjects under consideration here, ACTH was ad- 


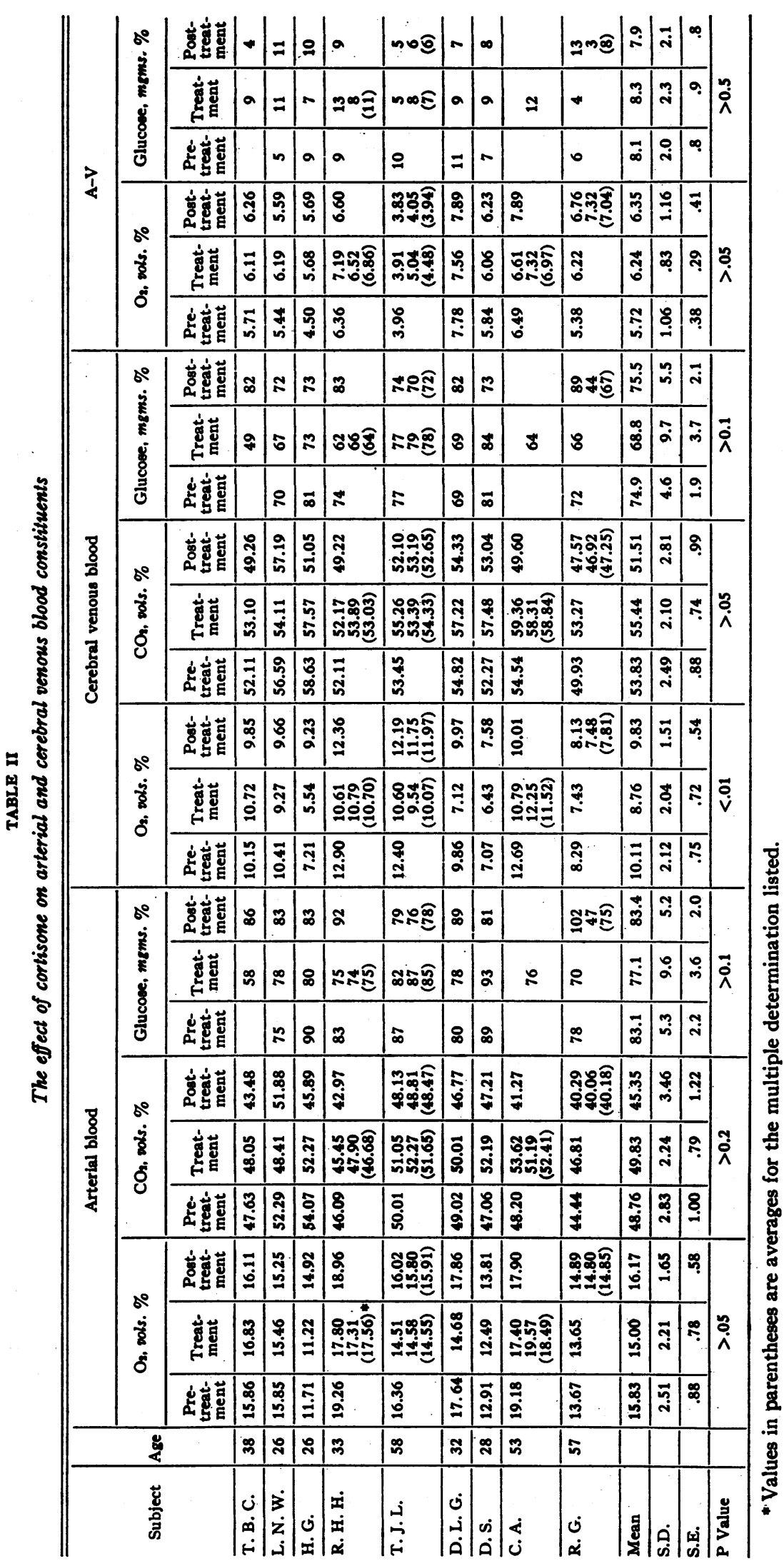


TABLE III

The effect of $A C T H$ on cerebral hemodynamic and metabolic functions

\begin{tabular}{|c|c|c|c|c|c|c|c|c|c|c|c|c|c|c|c|c|c|c|}
\hline \multirow{2}{*}{ Subject } & \multirow{2}{*}{ Diagnosis } & \multirow{2}{*}{ Age } & \multirow{2}{*}{$\begin{array}{c}\text { Daily } \\
\text { dose } \\
\text { ACTH } \\
\text { mgms./ } \\
\text { day }\end{array}$} & \multicolumn{3}{|c|}{$\begin{array}{c}\text { Cerebral blood } \\
\text { flow (CBF) } \\
\text { cc./min. } / 100 \mathrm{gms} .\end{array}$} & \multicolumn{3}{|c|}{$\begin{array}{c}\text { Cerebral vascular } \\
\text { resistance (CVR) } \\
\text { mm. Hg/ce./min./ } \\
100 \text { gms. }\end{array}$} & \multicolumn{3}{|c|}{$\begin{array}{c}\text { Mean arterial } \\
\text { blood pressure } \\
(\mathbf{M A B P}) \\
\text { mm. } \boldsymbol{H g}\end{array}$} & \multicolumn{3}{|c|}{$\begin{array}{l}\text { Cerebral metabolic } \\
\text { rate oxygen } \\
\text { (CMROM) } \\
\text { cc./min./100 gms. }\end{array}$} & \multicolumn{3}{|c|}{$\begin{array}{l}\text { Cerebral metabolic } \\
\text { rate glucose } \\
\text { (CMRglu) } \\
\text { mgms./min./100 gms. }\end{array}$} \\
\hline & & & & $\begin{array}{l}\text { Pre- } \\
\text { treat- } \\
\text { ment }\end{array}$ & $\begin{array}{l}\text { Treat- } \\
\text { ment }\end{array}$ & $\begin{array}{l}\text { Post- } \\
\text { treat- } \\
\text { ment }\end{array}$ & $\begin{array}{l}\text { Pre- } \\
\text { treat- } \\
\text { ment }\end{array}$ & $\begin{array}{l}\text { Treat- } \\
\text { ment }\end{array}$ & $\begin{array}{l}\text { Post- } \\
\text { treat- } \\
\text { ment }\end{array}$ & $\begin{array}{c}\text { Pre- } \\
\text { treat- } \\
\text { ment }\end{array}$ & $\begin{array}{l}\text { Treat- } \\
\text { ment }\end{array}$ & $\begin{array}{l}\text { Post- } \\
\text { treat- } \\
\text { ment }\end{array}$ & $\begin{array}{l}\text { Pre- } \\
\text { treat- } \\
\text { ment }\end{array}$ & $\begin{array}{l}\text { Treat- } \\
\text { ment }\end{array}$ & $\begin{array}{l}\text { Post- } \\
\text { treat- } \\
\text { ment }\end{array}$ & $\begin{array}{l}\text { Pre- } \\
\text { treat- } \\
\text { ment }\end{array}$ & $\begin{array}{l}\text { Treat- } \\
\text { ment }\end{array}$ & $\begin{array}{l}\text { Poot- } \\
\text { treat- } \\
\text { ment }\end{array}$ \\
\hline H. A. B. & $\begin{array}{l}\text { Rheumatoid } \\
\text { arthritis }\end{array}$ & 41 & $\begin{array}{l}100 \\
200\end{array}$ & 54 & $\begin{array}{c}63 \\
73 \\
(68) *\end{array}$ & 48 & 1.43 & $\begin{array}{c}1.33 \\
1.17 \\
(1.25)\end{array}$ & 1.68 & 77 & $\begin{array}{c}84 \\
86 \\
(85)\end{array}$ & 79 & 3.31 & $\begin{array}{c}3.63 \\
3.94 \\
(3.79)\end{array}$ & 2.64 & 4.86 & $\begin{array}{r}2.50 \\
7.30 \\
(4.90)\end{array}$ & \\
\hline J. J. N. & $\begin{array}{l}\text { Rheumatoid } \\
\text { arthritis }\end{array}$ & 25 & $\begin{array}{l}100 \\
200\end{array}$ & 67 & $\begin{array}{c}52 \\
79 \\
(66)\end{array}$ & 68 & 1.19 & $\begin{array}{c}1.62 \\
1.17 \\
(1.40)\end{array}$ & 1.12 & 80 & $\begin{array}{c}84 \\
93 \\
(89)\end{array}$ & 76 & 4.69 & $\begin{array}{c}3.97 \\
6.01 \\
(4.99)\end{array}$ & 4.01 & 8.71 & 5.72 & 7.48 \\
\hline W. F. G. & $\begin{array}{l}\text { Ulcerative } \\
\text { colitis }\end{array}$ & 46 & $\begin{array}{l}100 \\
100\end{array}$ & 49 & $\begin{array}{c}56 \\
65 \\
(61)\end{array}$ & & 1.46 & $\begin{array}{r}1.42 \\
1.26 \\
(1.34)\end{array}$ & & 69 & $\begin{array}{c}80 \\
82 \\
(81)\end{array}$ & & 3.51 & $\begin{array}{c}3.63 \\
3.46 \\
(3.55)\end{array}$ & & 6.58 & $\begin{array}{c}3.92 \\
5.85 \\
(4.89)\end{array}$ & \\
\hline H. H. & $\begin{array}{l}\text { Bronchial } \\
\text { asthma }\end{array}$ & 26 & 100 & & 47 & 62 & & 1.57 & 1.01 & & 74 & 63 & & 4.63 & 4.34 & & 6.58 & \\
\hline R. H. H. & $\begin{array}{l}\text { Rheumatoid } \\
\text { arthritis }\end{array}$ & 23 & 100 & 62 & 61 & & 1.16 & 1.45 & & 72 & 89 & & 3.81 & 4.94 & & & 3.05 & \\
\hline H. G. & $\begin{array}{l}\text { Ulcerative } \\
\text { colitis }\end{array}$ & 25 & 100 & 58 & 36 & 55 & 1.27 & 1.97 & 1.05 & 74 & 71 & 58 & 2.61 & 2.16 & 3.12 & 5.22 & 1.80 & 5.50 \\
\hline D. L. G. & Dermatitis & 31 & 100 & 53 & 53 & 52 & 1.35 & 1.66 & 1.36 & 72 & 88 & 71 & 4.12 & 4.11 & 4.10 & 5.83 & 5.83 & 3.64 \\
\hline A. L. D. & Dermatitis & 42 & 100 & 66 & 25 & 85 & 1.05 & 3.04 & 0.73 & 69 & 76 & 62 & 3.50 & 1.69 & 3.83 & 5.28 & 3.00 & 4.25 \\
\hline E. R. S. & $\begin{array}{l}\text { Rheumatoid } \\
\text { arthritis }\end{array}$ & 30 & $\begin{array}{r}120 \\
80 \\
20 \\
160 \\
20\end{array}$ & 76 & $\begin{array}{c}77 \\
76 \\
70 \\
84 \\
56 \\
(73)\end{array}$ & & 1.08 & $\begin{array}{l}1.01 \\
1.08 \\
1.20 \\
1.05 \\
1.52 \\
(1.17)\end{array}$ & & 82 & $\begin{array}{l}78 \\
82 \\
84 \\
88 \\
85 \\
(83)\end{array}$ & & 4.16 & $\begin{array}{c}4.65 \\
4.29 \\
5.10 \\
5.17 \\
3.46 \\
(4.53)\end{array}$ & & 5.32 & $\begin{array}{r}3.08 \\
5.32 \\
10.10 \\
3.36 \\
(5.47)\end{array}$ & \\
\hline J. R. B. & $\begin{array}{l}\text { Rheumatoid } \\
\text { arthritis }\end{array}$ & 29 & $\begin{array}{r}120 \\
80 \\
160 \\
120 \\
80 \\
80\end{array}$ & 59 & $\begin{array}{c}80 \\
82 \\
50 \\
41 \\
71 \\
60 \\
(64)\end{array}$ & & 1.33 & \begin{tabular}{|l|}
1.06 \\
1.01 \\
1.70 \\
2.14 \\
1.18 \\
1.30 \\
$(1.40)$
\end{tabular} & & 79 & $\begin{array}{c}85 \\
83 \\
85 \\
88 \\
84 \\
78 \\
(84)\end{array}$ & & 3.99 & $\begin{array}{c}4.38 \\
6.15 \\
4.07 \\
3.41 \\
5.10 \\
3.80 \\
(4.49)\end{array}$ & & 3.54 & $\begin{array}{c}9.02 \\
6.50 \\
5.74 \\
6.39 \\
4.20 \\
(6.37)\end{array}$ & \\
\hline L. R. C. & $\begin{array}{l}\text { Rheumatoid } \\
\text { arthritis }\end{array}$ & 36 & $\begin{array}{r}160 \\
120 \\
10 \\
160 \\
160\end{array}$ & 69 & $\begin{array}{c}65 \\
75 \\
75 \\
63 \\
51 \\
(66)\end{array}$ & & 1.09 & \begin{tabular}{|l|}
1.29 \\
1.17 \\
0.89 \\
1.37 \\
1.74 \\
$(1.27)$
\end{tabular} & & 75 & $\begin{array}{c}84 \\
88 \\
75 \\
86 \\
89 \\
(84)\end{array}$ & & 3.46 & $\begin{array}{c}3.77 \\
4.96 \\
4.29 \\
3.64 \\
3.96 \\
(4.12)\end{array}$ & & 2.07 & $\begin{array}{c}3.25 \\
7.50 \\
6.30 \\
5.10 \\
(5.54)\end{array}$ & \\
\hline L. A. E. & $\begin{array}{l}\text { Bronchial } \\
\text { asthma }\end{array}$ & & 100 & 57 & 75 & & 1.75 & 1.59 & & 100 & 119 & & 3.43 & 4.49 & & 7.40 & 9.00 & \\
\hline Mean & & & 111 & 60.9 & 57.9 & 61.7 & 1.29 & 1.59 & 1.16 & 77.2 & 85.3 & 68.2 & 3.69 & 3.96 & 3.67 & 5.48 & 5.25 & 5.22 \\
\hline S.D. & & & & 7.6 & 15.1 & 12.3 & .61 & .50 & .30 & 8.3 & 11.6 & 7.7 & .52 & 1.08 & .60 & 1.77 & 1.70 & 1.47 \\
\hline S.E. & & & & 3.2 & 4.4 & 5.5 & .19 & .15 & .13 & 2.6 & 3.5 & 3.5 & .17 & .33 & .30 & .59 & .57 & .85 \\
\hline P Value & & & & \multicolumn{3}{|c|}{$>0.5$} & \multicolumn{3}{|c|}{$>.05$} & \multicolumn{3}{|c|}{$<.001$} & \multicolumn{3}{|c|}{$>0.3$} & \multicolumn{3}{|c|}{$>0.7$} \\
\hline
\end{tabular}

* Values in parentheses are averages for the multiple determination listed.

ministered in varying amounts during a three to eight month period of time. The dosage schedule, duration of treatment, and the results of repeated measurements of cerebral hemodynamic and metabolic functions in these subjects are presented in Table V. It can be seen that there is a wide variation in all functions during the extended administration of ACTH. No apparent relationship exists between these variations and (a) duration of treatment, (b) size of the daily dosage of ACTH, or (c) changes in the arterial and cerebral venous blood constituents. There is no evidence to suggest that they were related to changes in the clinical status of the disease for which the patients were being treated.

Cushing's syndrome. Data on the cerebral circulation have been obtained from two patients suffering from advanced Cushing's syndrome (Table VI), associated with bilateral adrenal hyperplasia. The first patient, B. L. G., was untreated when the studies were done. There is a well marked increase in CVR (2.04 mm. $\mathrm{Hg}$ per 


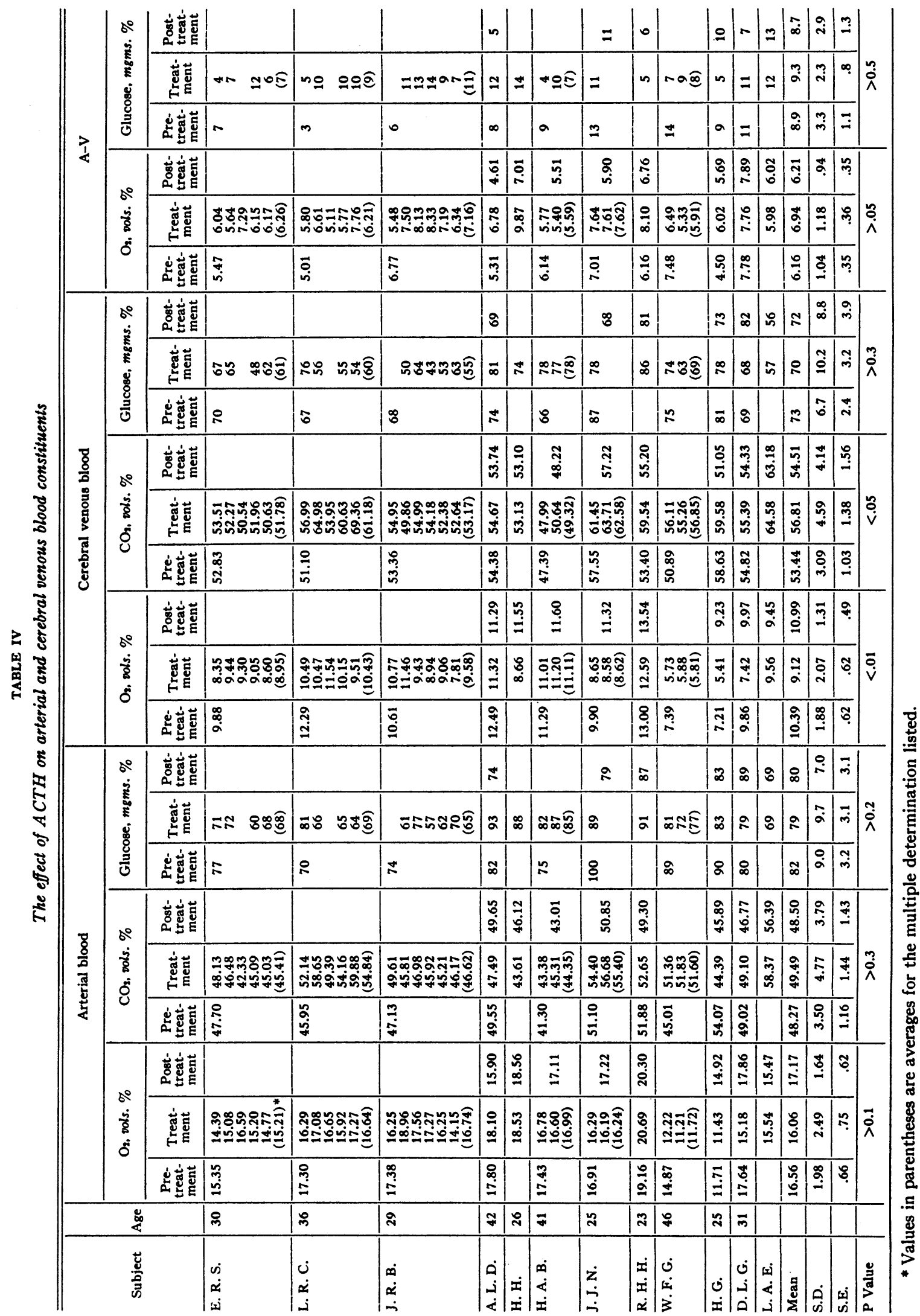


TABLE V

Cerebral hemodynamic and metabolic functions in three subjects to whom ACTH was administered continuously in varying amounts over periods of from three to eight months

\begin{tabular}{|c|c|c|c|c|c|c|c|c|c|}
\hline Subject & Age & Disease & $\begin{array}{c}\text { Mgms. of } \\
\text { ACTH/24 } \\
\text { hours being } \\
\text { administered } \\
\text { at time studies } \\
\text { were made }\end{array}$ & $\begin{array}{c}\text { Duration of } \\
\text { treatment } \\
\text { in days } \\
\text { at time } \\
\text { studies } \\
\text { were made }\end{array}$ & $\begin{array}{c}\text { CBF } \\
c c . / m i n . / \\
100 \text { gms. }\end{array}$ & 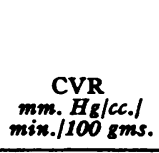 & $\begin{array}{l}\text { MABP } \\
m m . H_{g}\end{array}$ & $\begin{array}{l}\text { CMROA } \\
c c . / 2 m i n .1 \\
100 \mathrm{gms} .\end{array}$ & $\begin{array}{c}\text { CMRglu } \\
\text { mgms. } / \text { minin. } \\
100 \mathrm{gms} . \\
\end{array}$ \\
\hline J. R. B. & 29 & $\begin{array}{l}\text { Rheumatoid } \\
\text { arthritis }\end{array}$ & $\begin{array}{r}0 \\
120 \\
80 \\
160 \\
120 \\
80 \\
80\end{array}$ & $\begin{array}{r}0 \\
6 \\
36 \\
72 \\
101 \\
155 \\
245\end{array}$ & $\begin{array}{l}59 \\
80 \\
82 \\
50 \\
41 \\
71 \\
60\end{array}$ & $\begin{array}{l}1.33 \\
1.06 \\
1.01 \\
1.70 \\
2.14 \\
1.18 \\
1.30\end{array}$ & $\begin{array}{l}79 \\
85 \\
83 \\
85 \\
88 \\
84 \\
78\end{array}$ & $\begin{array}{l}3.99 \\
4.38 \\
6.15 \\
4.07 \\
3.41 \\
5.10 \\
3.80\end{array}$ & $\begin{array}{l}3.54 \\
9.02 \\
6.50 \\
5.74 \\
6.39 \\
4.20\end{array}$ \\
\hline E. R.S. & 30 & $\begin{array}{l}\text { Rheumatoid } \\
\text { arthritis }\end{array}$ & $\begin{array}{r}0 \\
120 \\
80 \\
20 \\
160 \\
20\end{array}$ & $\begin{array}{r}0 \\
4 \\
33 \\
69 \\
84 \\
147\end{array}$ & $\begin{array}{l}76 \\
77 \\
76 \\
70 \\
84 \\
56\end{array}$ & $\begin{array}{l}1.08 \\
1.01 \\
1.08 \\
1.20 \\
1.05 \\
1.52\end{array}$ & $\begin{array}{l}82 \\
78 \\
82 \\
84 \\
88 \\
85\end{array}$ & $\begin{array}{l}4.16 \\
4.65 \\
4.29 \\
5.10 \\
5.17 \\
3.46\end{array}$ & $\begin{array}{r}5.32 \\
3.08 \\
5.32 \\
10.10 \\
3.36\end{array}$ \\
\hline L. R. C. & 36 & $\begin{array}{l}\text { Rheumatoid } \\
\text { arthritis }\end{array}$ & $\begin{array}{r}0 \\
160 \\
120 \\
10 \\
160 \\
160\end{array}$ & $\begin{array}{r}0 \\
6 \\
16 \\
57 \\
65 \\
86\end{array}$ & $\begin{array}{l}69 \\
65 \\
75 \\
75 \\
63 \\
51\end{array}$ & $\begin{array}{l}1.09 \\
1.29 \\
1.17 \\
0.89 \\
1.37 \\
1.74\end{array}$ & $\begin{array}{l}75 \\
84 \\
88 \\
75 \\
86 \\
89\end{array}$ & $\begin{array}{l}3.46 \\
3.77 \\
4.96 \\
4.29 \\
3.64 \\
3.96\end{array}$ & $\begin{array}{l}2.07 \\
3.25 \\
7.50 \\
6.30 \\
5.10\end{array}$ \\
\hline
\end{tabular}

cc. per min. per 100 gms.) and MABP (137 mm. $\mathrm{Hg}$ ). CBF (67 cc. per min. per 100 gms.), $\mathrm{CMR}_{\mathrm{O}_{2}}$ (4.13 cc. per min. per 100 gms.), and CMRglu (5.36 mgms. per min. per 100 gms.) are well within normal limits. In the second patient, F. V. B., the studies were made after the institution of an intensive and generally satisfactory program of treatment which included irradiation of the pituitary gland, sodium restriction, and the administration of supplementary potassium. The blood pressure had returned to near normal levels, the edema had been controlled, and the metabolic alkalosis corrected at the time the studies were made. The CVR (1.59 mm. Hg per cc. per min. per 100 gms.) and MABP (92 mm. $\mathrm{Hg}$ ) are slightly increased above the mean values for normal men of this age group. Cerebral blood flow (58 cc. per min. per 100 gms.), CMR $\mathrm{O}_{2}$ (4.12 cc. per min. per 100 gms.), and CMRglu (6.38 mgms. per min. per 100 gms.) are well within normal limits.

\section{DISCUSSION}

A consideration of the mean values of the functions measured in these two groups of patients shows that the CBF is not altered by the administration of cortisone or ACTH. These results are similar to those of Alman and Fazekas (5), who found no changes in cerebral hemodynamics or metabolism in a small group of patients during the first three to four days of administration of ACTH. Schieve, Scheinberg, and Wilson (6), however, in a larger series of patients, treated over a longer period of time, a study more comparable to the present one, found a significant decrease in $\mathrm{CBF}$ during the administration of ACTH. This was a consequence of a marked increase in calculated mean CVR. Their findings suggest that the increase in vascular resistance that has occurred in the brain is of greater magnitude than that of the body as a whole. The findings of this study, on the other hand, would indicate that the increase in cerebral vascular tone that may occur during the administration of ACTH and cortisone is simply a reflection of the increase in total peripheral resistance. Hemodynamically, the changes are identical to those known to exist in essential hypertension, i.e., parallel increases in MABP and CVR; normal CBF (7). The increases in mean arterial and cerebral venous $\mathrm{CO}_{2}$ content observed during treatment with both cortisone and ACTH are slight and are not statistically significant except in the case of the cerebral venous blood in the ACTH series. Nevertheless, they may re- 


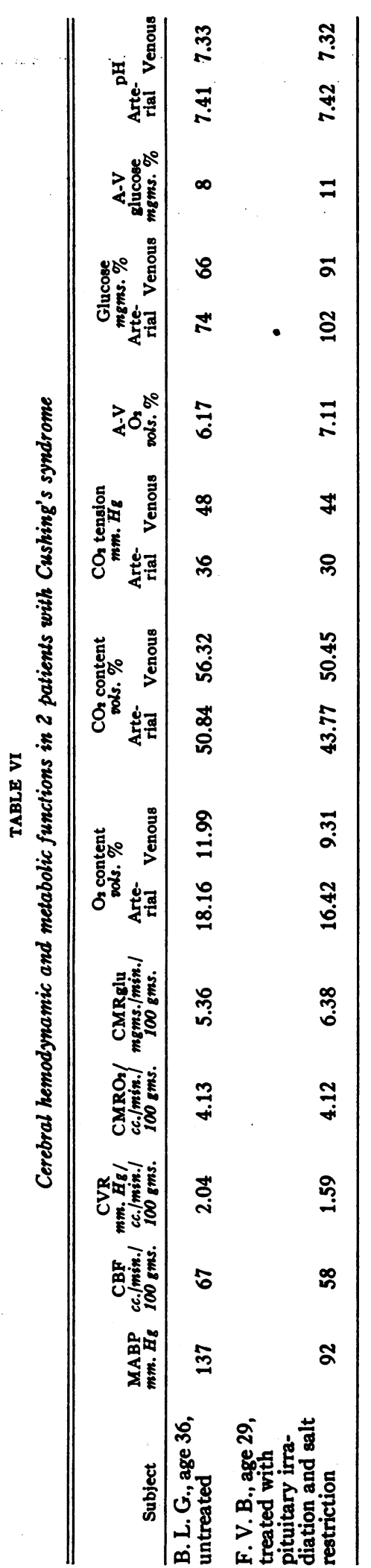

flect the presence of a mild metabolic alkalosis in these subjects. Unfortunately, our data on blood $\mathrm{pH}$ are inadequate to substantiate this point. The small reduction in mean arterial and cerebral venous blood sugar that occurred during the administration of both cortisone and ACTH may have been a consequence of increased insulin production or decreased production of growth hormone, or both (8-11).

A consideration of individual subjects in both the cortisone and ACTH treated series reveals an occasional instance in which a striking reduction in $\mathrm{CBF}$ occurred during the administration of the drug, with return to its control value after treatment was discontinued. (H. G. and A. L. D. in the ACTH series and T. J. L. in the cortisone series.) The remainder of the cases fall in general into two groups: (a) those in whom a parallel rise in MABP and CVR occurred without a change in CBF and ; (b) those in whom the CVR was unchanged, with variations in CBF apparently dependent upon changes in MABP.

In those patients studied repeatedly during the long continued administration of ACTH, no changes in cerebral hemodynamics or metabolism were observed that could be attributed to the drug, the size of the dosage or duration of administration.

The data provide no clear explanation for the cause of the increase in CVR observed in the majority of patients who are treated with ACTH or cortisone, and in the patients with an endogenous abundance of adrenal cortical hormones due to Cushing's syndrome. The cerebral blood vessels are known to show profound vasomotor responses to changes in blood $\mathrm{CO}_{2}$ tension, $\mathrm{O}_{2}$ tension, and $\mathrm{pH}$ (12), but the observed hemodynamic alterations could not be correlated with changes in blood gases. It is unlikely that the increases in arterial and venous $\mathrm{CO}_{2}$ content during treatment, which are suggestive of the presence of mild metabolic alkalosis, are related to the cerebral circulatory changes that occurred, since experimental alkalosis in humans is known to dilate rather than constrict cerebral vessels and is accompanied by an increase in CBF (13). It seems most likely that the hemodynamic changes in the cerebral circulation simply reflect changes occurring in the general circulation. The findings do not support the contention that ACTH or cortisone consistently 
exerts a specific local effect on the cerebral vasculature. In an occasional individual there occurs a reduction in $\mathrm{CBF}$, of such magnitude and reversibility when the drug is withdrawn, to suggest strongly that a degree of cerebral vasoconstriction has been induced that is out of proportion to the increase in total peripheral resistance manifest in that individual. The cause for this apparent local increase in CVR in an occasional patient is not known. Changes in blood $\mathrm{O}_{2}$ content or $\mathrm{CO}_{2}$ content of sufficient magnitude to account for them did not occur; they are too large to be within the range of normal variation; we have no reason to believe they are the result of technical errors; they do not appear to be related to changes in the clinical course of the diseases for which the patients were being treated.

In spite of the profound metabolic effects of ACTH and cortisone, and the fact that the adrenal steroids traverse the blood-brain barrier and might easily affect cerebral enzyme systems, the administration of these hormones did not alter the total oxygen or glucose consumption of the brain. However, all the patients exhibited some change in personality of greater or lesser degree during the course of treatment. Most of them developed a positive sense of well being, irrespective of the clinical status of their disease; some became euphoric, one (W. F. G.) suddenly became belligerent and expressed ideas of persecution. One of the patients (L. R. C.) who received ACTH for several months became frankly psychotic after a long period of progressive change in mood. No correlation exists between these mental changes and the cerebral circulatory and metabolic functions that were measured. These data support the concept that the bulk of oxygen and glucose consumed by the brain is used to maintain its structural integrity and throw no light on the biochemical or biophysical changes associated with changes in mentation.

\section{SUM MARY}

1. Measurements of cerebral circulatory and metabolic functions were made in a series of patients before, during, and after treatment with cortisone and ACTH. Similar studies were made in two patients with Cushing's syndrome.

2. Parallel increases in the means of arterial blood pressure and cerebral vascular resistance occurred in both the cortisone and ACTH treated patients. The mean cerebral blood flow remained unchanged. The results are interpreted to mean that the cerebral circulation shares equally in an increase in general peripheral vascular resistance. ACTH and cortisone do not appear to exert a specific, local effect upon cerebral blood vessels. Similar changes in the cerebral circulation, that is, parallel increases in MABP and in CVR, with normal CBF were found in two subjects with Cushing's syndrome.

3. Significant changes in the mean cerebral utilization of oxygen and glucose did not occur during the administration of cortisone or ACTH. Cerebral oxygen and glucose utilization were normal in patients with Cushing's syndrome.

4. These studies provide no explanation for the mental changes that occurred during the administration of cortisone and ACTH.

\section{ACKNOWLEDGMENTS}

This work was done with the technical assistance of Mrs. Angeline M. Hayes and Miss Mary Sue McCall. Mr. Tyree Loving also gave valuable assistance.

\section{REFERENCES}

1. Plotz, C. M., Knowlton, A. I., and Ragan, C., The natural history of Cushing's syndrome. Am. J. Med., 1952, 13, 597.

2. Kety, S. S., and Schmidt, C. F., The nitrous oxide method for the quantitative determination of cerebral blood flow in man: Theory, procedure and normal values. J. Clin. Invest., 1948, 27, 476.

3. Scheinberg, P., and Stead, E. A., Jr., The cerebral blood flow in male subjects as measured by the nitrous oxide technique. Normal values for blood flow, oxygen utilization, glucose utilization and peripheral resistance, with observations on the effect of tilting and anxiety. J. Clin. Invest., 1949, 28, 1163.

4. Nelson, N., A photometric adaptation of the Somogyi method for the determination of glucose. J. Biol. Chem., 1944, 153, 375.

5. Alman, R. W., and Fazekas, J. F., Effects of ACTH on cerebral blood flow and oxygen consumption. Arch. Neurol. \& Psychiat., 1951, 65, 680.

6. Schieve, J. F., Scheinberg, P., and Wilson, W. P., The effect of adrenocorticotrophic hormone (ACTH) on cerebral blood flow and metabolism. J. Clin. Invest., 1951, 30, 1527.

7. Kety, S. S., Hafkenschiel, J. H., Jeffers, W. A., Leopold, I. H., and Schenkin, H. A., The blood flow, vascular resistance, and oxygen consumption of the brain in essential hypertension. J. Clin. Invest., 1948, 27, 511. 
8. Sprague, R. G., Power, M. H., Mason, H. L., Albert, A., Mathieson, D. R., Hench, P. S., Kendall, E. C., Slocumb, C. H., and Polley, H. F., Observations on the physiologic effects of cortisone and ACTH in man. Arch. Int. Med., 1950, 85, 199.

9. Thorn, G. W., Forsham, P. H., Frawley, T. F., Hill,

S. R., Jr., Roche, M., Staehelin, D., and Wilson, D. L., The clinical usefulness of ACTH and cortisone. New England J. Med., 1950, 242, 783-793, 824-834, 865-872.

10. Thorn, G. W., Koepf, G. F., Lewis, R. A., and Olsen, E. F., Carbohydrate metabolism in Addison's Disease. J. Clin. Invest., 1940, 19, 813.
11. Sprague, R. G., Mason, H. L., and Power, M. H., Studies of effects of adrenal cortical hormones on carbohydrate metabolism in human subjects. Proc. Am. Diabetes A., 1949, 9, 147.

12. Kety, S. S., and Schmidt, C. F., The effects of altered arterial tensions of carbon dioxide and oxygen on cerebral blood flow and cerebral oxygen consumption of normal young men. J. Clin. Invest., 1948, $27,484$.

13. Schieve, J. F., and Wilson, W. P., The changes in cerebral vascular tone in experimental metabolic alkalosis and acidosis. J. Clin. Invest., 1952, 31, 659. 